\title{
Studio Education at FA CTU, its Current and Possible Structuring
}

ADÉLA CHMELOVÁ

The Faculty of Architecture, Czech Technical University in Prague 
Recently, I left the educational process at the Faculty of architecture and was given the opportunity to work as an assistant at the studio classes (so-called atelier). As a fresh graduate, I entered the teaching process with the student's insight, but gradually I was confronted with the situation on the 'other side'. The position of the fresh graduate has many advantages. For example, still up-to-date insight into the bureaucratic system of the faculty - with other words, knowing how it goes. On the other hand, one encounters questions: how to teach properly? In the present days a new field of study is still forming at the faculty: Landscape architecture, which was previously brought into the curriculum in the form of a module focused on garden and landscape architecture. There is room for some possible changes. At the faculty, questions also are arising on what the ideal composition of subjects of this newly shaped field should be, how much it has to do with architecture and how it is projecting in the environment disciplines.

Studio education is a complex activity that includes knowledge from all subjects, but it should be given more attention and time. The architect knows something about everything, merging knowledge from many disciplines to a specific goal (Frederick, 2007). It is necessary to support the involvement of many subjects in studio education so that they cooperate and do not go against each other. Time subsidies for teaching in individual subjects are often very limited. During this short time, as much information as possible is being put into students and various seminar papers are given. Time subsidies for some of these courses could be used and thematically harmonized with studio education so that the student gets deeper into the assignment and connects the task in all its complexity. Ideally, students should apply the knowledge from individual subjects and work further with them during studio lessons rather than supplement them. People must learn synthesis to blend and transfer knowledge (Liesmann 2009), while their separation provides a knowledge that can be quickly achieved, quickly mastered and easily forgotten (ibid). This method of joining them in studio would certainly help the synthesis of knowledge. Often, direct experience helps to remember. In some studios, it is common to implement the realization of the student's proposal even during the semester. However, it is necessary to involve even more external assistance. Paper can withstand everything, but a lot of problems come out when trying to realize the design proposal. Excursions and meetings with project authors are also quite helpful. The discussion on the work itself during the field survey engraves into student minds much better than projected images. 
However, as an indisputable advantage of studio classes at our faculty, I perceive vertical studios. Students from different grades can share their experiences and pass them on. The so-called self-consultation among students is often very useful, especially in cases when they solve a similar problem in the project. Solving the problem, the process leading to the result is as important as the result itself. A great asset in our studio is also a relatively high representation of international students, either they are regular students studying in the English language or the exchange students. They can also contribute with their insight unbiased for the Czech environment. I think that confronting students with different stimuli and influences is one of the most important things, as well as supporting their participation in competitions, subsequent comparing with other teams and approaches.

One more aspect should be mentioned. A fresh insight into how to educate architects is, for example, the approach of the Czech platform Architekti ve škole (Architects at school). This is not just about teaching future architects, but also educating potential clients. A future architect should also be able to have a meaningful dialogue with his clients. This platform seeks to educate children from an early age in the field of architecture, from playing games in kindergarten to introducing content to older children at grammar schools. The aim of this movement is to understand the architect's language, to understand its role and to cultivate a sense of aesthetics. The establishment of a children's university at CTU in 2015 can also be seen as a certain shift, when children during the holiday season absorb the environment of individual technical fields, including architecture.

The less obvious aspect of these efforts is cultivating respect towards the architect as an expert with professional skills that the client can enter dialogue with. An architect with synthetic knowledge and experience that he can use comprehensively

- and clients who can talk to him - are the fundaments in $N$
0 cultivating our environment.

\section{REFERENCES}

Frederick, Matthew. 101 Things I Learned in Architecture School. MIT Press, 2007. ISBN 978-0262062664

Liessman, Konrad Paul. Teorie nevzdělanosti. Praha: Academia, 2009. ISBN 978-80-200-1677-5 (from the original Theorie der Unbildung. Die Irrtümer der Wissensgesellschaft. Wien: Paul Zsolnay Verlag, 2007. Translated Jana Zoubková)

Architekti ve škole. 2014. O platformě. [ONLINE] Available at: http://www.architektiveskole.cz/. [Accessed 13 June 2019]. 


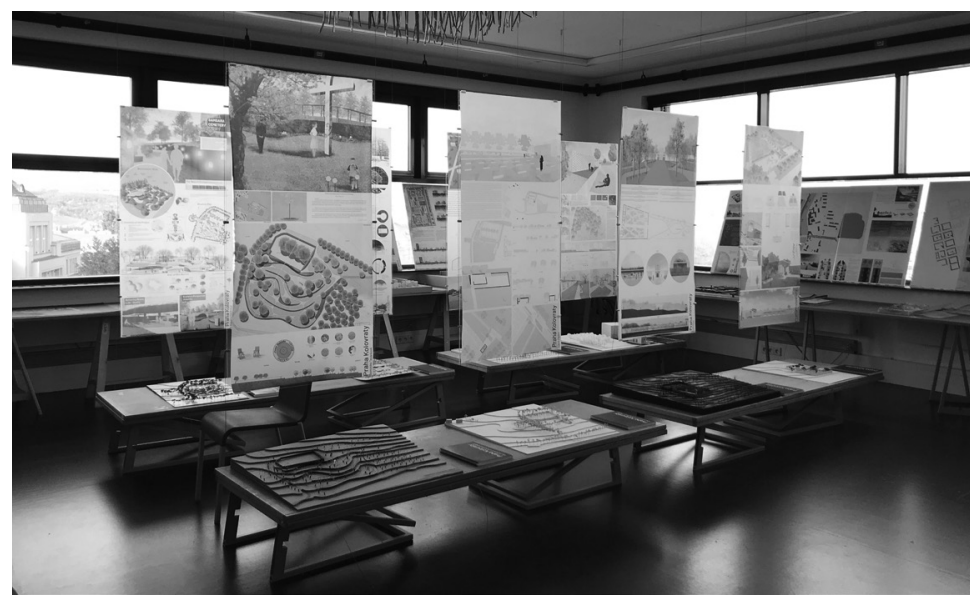

1: Final exhibition of student works including poster, physical model and portfolio

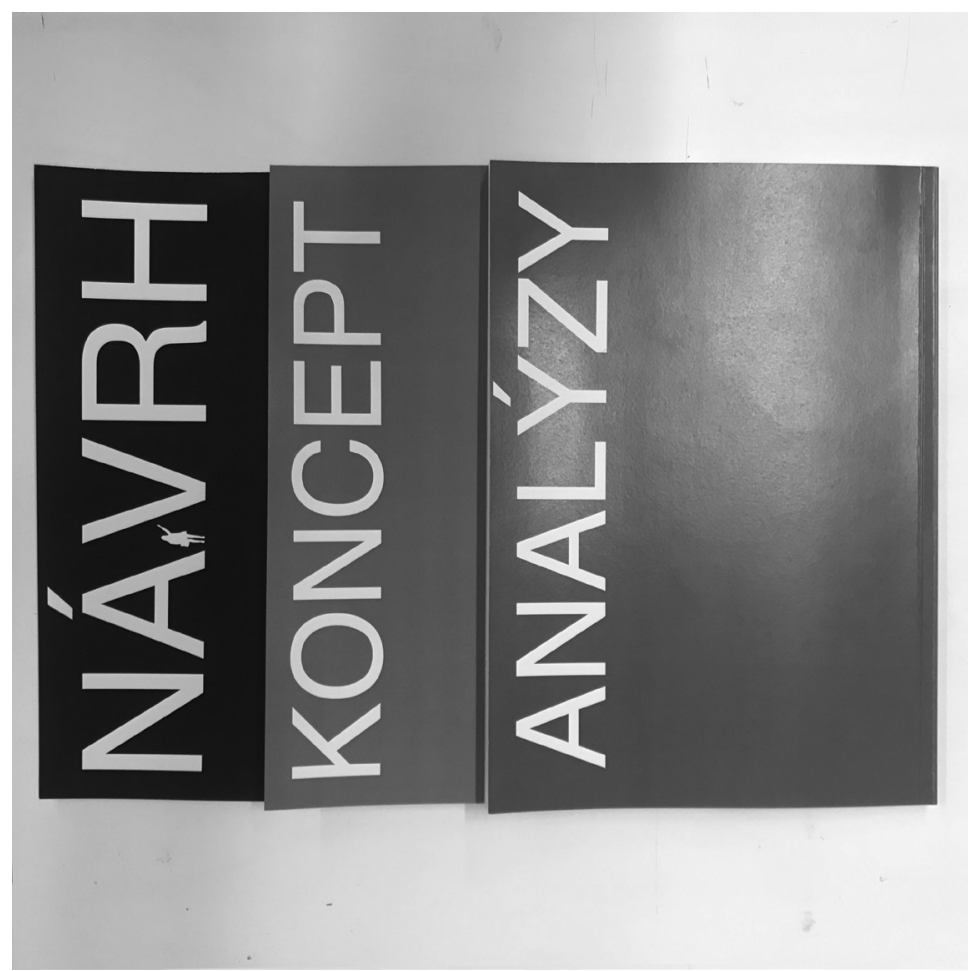

2: Studio work divided into three main parts - an analytical one, a conceptual one and design itself (portfolios of students Anžka Vonášková and Kateřina Beránková) 


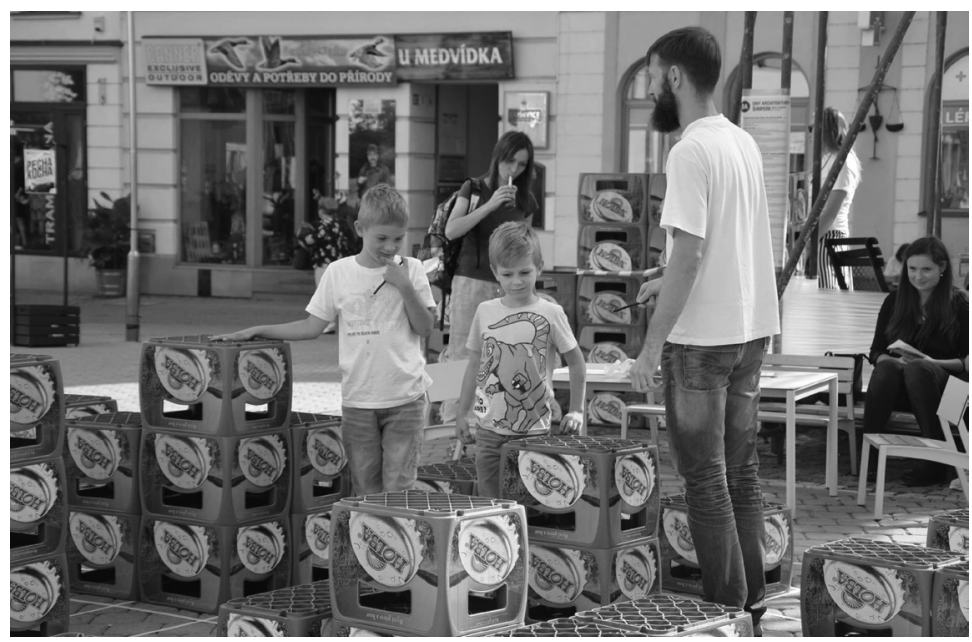

3: Illustrating activity of Architects in schools (Architekti ve škole), showing children workshop during festival Architecture day (Den architektury) in Sumperk in the Czech republic

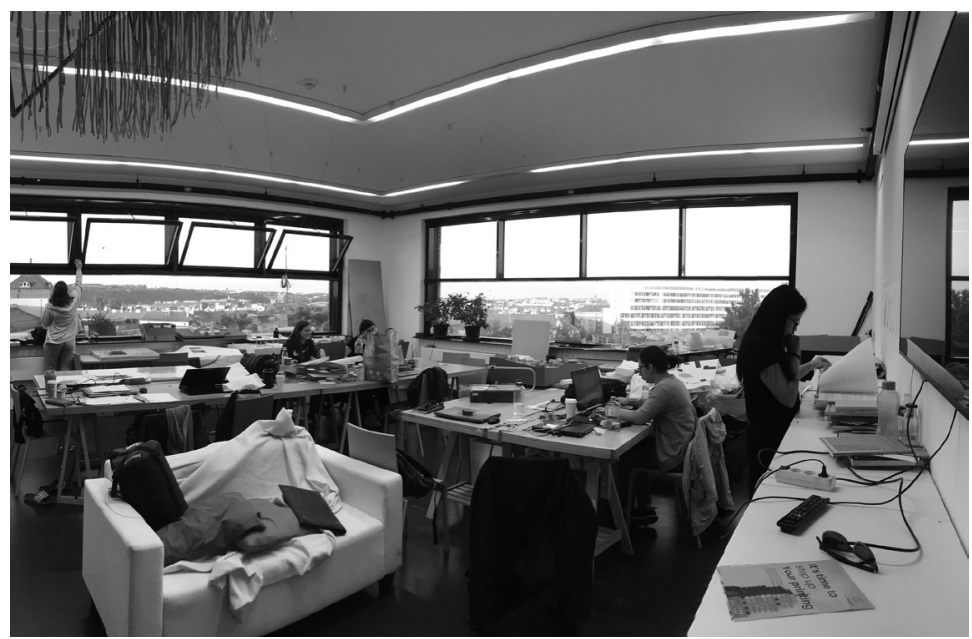

4: Illustrating vertical studio with students from different semesters working together 


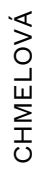

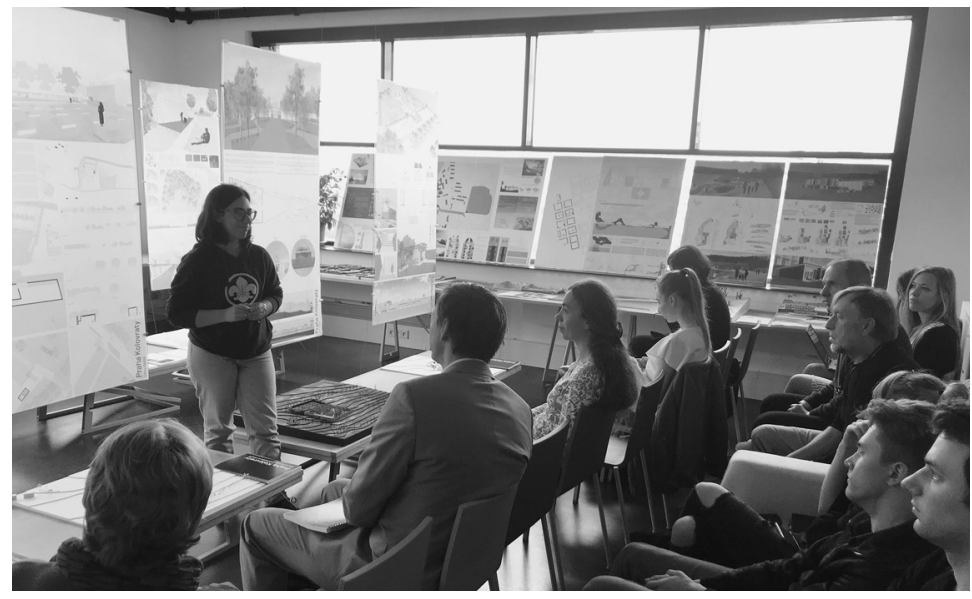

5: Also representing vertical studios from final project presentation

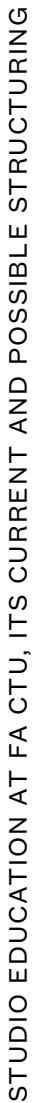

